\title{
Molecular Mechanisms of Acetaldehyde-Mediated Carcinogenesis in Squamous Epithelium
}

\author{
Ayaka Mizumoto ${ }^{1}$ (D), Shinya Ohashi ${ }^{1}$, Kenshiro Hirohashi ${ }^{2}$, Yusuke Amanuma ${ }^{1}$, \\ Tomonari Matsuda ${ }^{3}$ and Manabu Muto ${ }^{1, *}$ \\ 1 Department of Therapeutic Oncology, Graduate School of Medicine, Kyoto University, Kyoto 606-8507, \\ Japan; ayaka@kuhp.kyoto-u.ac.jp (A.M.); ohashish@kuhp.kyoto-u.ac.jp (S.O.); \\ yusuke12@kuhp.kyoto-u.ac.jp (Y.A.) \\ 2 Department of Gastroenterology and Hepatology, Graduate School of Medicine, Kyoto University, \\ Kyoto 606-8507, Japan; kenshiro@kuhp.kyoto-u.ac.jp \\ 3 Research Center for Environmental Quality Management, Kyoto University, Otsu 520-0811, Japan; \\ matsuda.tomonari.8z@kyoto-u.ac.jp \\ * Correspondence: mmuto@kuhp.kyoto-u.ac.jp; Tel.: +81-075-751-4592; Fax: +81-075-751-4594
}

Received: 28 July 2017; Accepted: 7 September 2017; Published: 10 September 2017

\begin{abstract}
Acetaldehyde is a highly reactive compound that causes various forms of damage to DNA, including DNA adducts, single- and/or double-strand breaks (DSBs), point mutations, sister chromatid exchanges (SCEs), and DNA-DNA cross-links. Among these, DNA adducts such as $N^{2}$-ethylidene-2'-deoxyguanosine, $N^{2}$-ethyl-2'-deoxyguanosine, $N^{2}$-propano-2'-deoxyguanosine, and $N^{2}$-etheno-2'-deoxyguanosine are central to acetaldehyde-mediated DNA damage because they are associated with the induction of DNA mutations, DNA-DNA cross-links, DSBs, and SCEs. Acetaldehyde is produced endogenously by alcohol metabolism and is catalyzed by aldehyde dehydrogenase 2 (ALDH2). Alcohol consumption increases blood and salivary acetaldehyde levels, especially in individuals with $A L D H 2$ polymorphisms, which are highly associated with the risk of squamous cell carcinomas in the upper aerodigestive tract. Based on extensive epidemiological evidence, the International Agency for Research on Cancer defined acetaldehyde associated with the consumption of alcoholic beverages as a "group 1 carcinogen" (definite carcinogen) for the esophagus and/or head and neck. In this article, we review recent advances from studies of acetaldehyde-mediated carcinogenesis in the squamous epithelium, focusing especially on acetaldehyde-mediated DNA adducts. We also give attention to research on acetaldehyde-mediated DNA repair pathways such as the Fanconi anemia pathway and refer to our studies on the prevention of acetaldehyde-mediated DNA damage.
\end{abstract}

Keywords: acetaldehyde; DNA adduct; esophageal squamous cell carcinoma; head and neck squamous cell carcinoma; DNA damage; cancer development; DNA repair pathway

\section{Acetaldehyde, Acetaldehyde Metabolism, and Risk of Cancers}

Acetaldehyde, a low molecular weight organic aldehyde with the formula $\mathrm{CH}_{3} \mathrm{CHO}$, is a highly reactive compound that causes DNA damage [1,2]. It is found in food and drinks such as yogurt, ripe fruits, cheese, coffee, and alcoholic beverages [3,4], and in tobacco smoke [5]. In addition, acetaldehyde can be produced by microorganisms such as yeasts and bacteria in the human oral cavity [6-8]. Thus, acetaldehyde can be ingested orally in a variety of ways. In particular, alcoholic beverages such as Calvados and other spirits contain high quantities of "free" acetaldehyde (e.g., Calvados: $1781 \pm 861 \mu \mathrm{M})$, and frequent consumption of these beverages is associated with an increased risk of esophageal squamous cell carcinoma (ESCC) [4,9], although "free" acetaldehyde present in alcoholic beverages appears to cause only a short time (1-2 $\mathrm{min})$ direct exposure to the organs [10]. 
More importantly, acetaldehyde is also generated endogenously by alcohol metabolism. Ingested alcohol is absorbed from the upper gastrointestinal tract and transported to the liver, where it is mainly metabolized into acetaldehyde by alcohol dehydrogenase 1B (ADH1B), and then detoxified to acetic acid by aldehyde dehydrogenase 2 (ALDH2) (Figure 1) [11,12]. Genetic polymorphisms in $A D H 1 B$ and/or $A L D H 2$ can result in different enzymatic activities that have a major impact on the risk of ESCC as well as head and neck squamous cell carcinoma (HNSCC) [13-16].

ADH1B has two alleles, $A D H 1 B^{*} 1$ (less active ADH1B) and $A D H 1 B^{*} 2$ (active ADH1B, Arg47His). Therefore, $\mathrm{ADH} 1 \mathrm{~B}$ is divided into three genotypes; $A D H 1 B^{*} 1{ }^{*} 1$, less active slow metabolizing $\mathrm{ADH} 1 \mathrm{~B}$, and $A D H 1 B^{*} 1{ }^{*} 2$ and $A D H 1 B^{*} 2 /{ }^{*}$, active ADH1B [17]. Since alcohol metabolism is slow in individuals homozygous for $A D H 1 B^{*} 1{ }^{*} 1$, acetaldehyde remains in the body for a long time. Meta-analysis has shown that individuals with $A D H 1 B^{*} 1{ }^{*} 1$ have a 2.77 - and 2.35 -fold increased risk of ESCC [18] and HNSCC [19], respectively, compared with carriers of the $A D H 1 B^{*} 2$ allele $\left(A D H 1 B^{*} 1{ }^{*} 2\right.$ and $A D H 1 B^{*} 2 /{ }^{*}$ ).

ALDH2 has two alleles, $A L D H 2 * 1$ (active ALDH2) and ALDH2*2 (inactive ALDH2, Glu504Lys). As ALDH2 is a tetrameric enzyme and $A L D H 2 * 2$ acts in a dominant negative manner, the phenotypic loss of ALDH2 activity is found in both heterozygous $\left(A L D H 2 * 1 /{ }^{*} 2\right)$ and homozygous $\left(A L D H 2 * 2 /{ }^{*} 2\right)$ genotypes [20,21]. Subsequently, ALDH2 genotypes are classified as follows: $A L D H 2{ }^{*} 1 /{ }^{*} 1$, active $(100 \%$ activity) ALDH2; $A L D H 2 * 1 / * 2$, inactive ( $<10 \%$ activity) $\mathrm{ALDH} 2$; and $A L D H 2 * 2 \% 2$, inactive ( $0 \%$ activity) ALDH2 [22]. Carriers of the $A L D H 2 * 2$ allele $\left(A L D H 2 * 1 / * 2\right.$ and $\left.A L D H 2 * 2 /{ }^{*}\right)$ account for approximately $40 \%$ of East Asian populations [23-25], whereas these genotypes are quite rare in Caucasoid or Negroid populations [26]. Meta-analysis has shown that individuals with $A L D H 2^{*} 1 /{ }^{*} 2$ have a 7.12 - and 1.83 -fold increased risk of ESCC [14] and HNSCC [27], respectively, compared with carriers of $A L D H 2^{*} 1 /{ }^{*} 1$. Moreover, alcoholics with the $A L D H 2^{*} 1 /{ }^{*} 2$ genotype have a 13.5- and 18.52-fold increased risk of ESCC and HNSCC, respectively, compared with $A L D H 2^{*} 1 /{ }^{*} 1$ genotypes [15].

Thus, extensive epidemiological evidence suggests that acetaldehyde is deeply involved in the carcinogenesis of the squamous epithelium of the esophagus, and head and neck. In addition, the International Agency for Research on Cancer has defined acetaldehyde associated with the consumption of alcoholic beverages as a "group 1 carcinogen" (definite carcinogen) for the esophagus and/or head and neck [28].

$$
\text { Ethanol } \stackrel{\text { ADH1B }}{\longrightarrow} \text { Acetaldehyde } \stackrel{\text { ALDH2 }}{\longrightarrow} \text { Acetic acid }
$$

Figure 1. Ethanol and acetaldehyde metabolism after alcohol ingestion. Ethanol is metabolized to acetaldehyde by alcohol dehydrogenase 1B (ADH1B), and then acetaldehyde is degraded to acetic acid by aldehyde dehydrogenase 2 (ALDH2).

\section{Field Cancerization in the Esophagus, and Head and Neck}

In some patients, ESCC occurs synchronously and/or metachronously in conjunction with HNSCC (Figure 2A) [12,29]. In such patients, widespread epithelial oncogenic alterations are frequently observed in the esophagus and can be visible as multiple Lugol-voiding lesions (LVLs) by Lugol chromoendoscopy (Figure 2B) [30,31]. Thus, multiple occurrences of neoplastic changes in the upper aerodigestive tract have been explained by the phenomenon of "field cancerization" [32]. We reported previously that the $A L D H 2 * 2$ allele is the strongest contributing factor (OR: 17.6) for the development of multiple LVLs [29]. Our recent prospective cohort study also revealed that the severity of LVLs is associated with the amount of average alcohol consumption, and individuals with multiple LVLs in their esophagus are especially at high risk for metachronous multiple ESCC and HNSCC [33]. Thus, alcohol consumption in individuals with the $A L D H 2 * 2$ allele is proven to be associated with the development of field cancerization in the esophagus, and head and neck. 


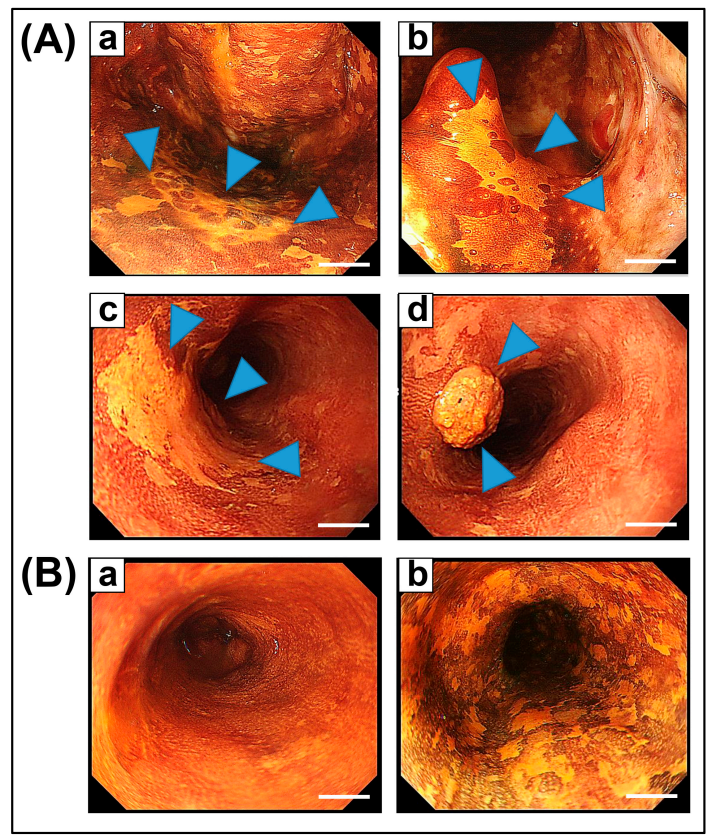

Figure 2. Lugol chromoendoscopic images. (A): "Field cancerization" in a patient with esophageal squamous cell carcinoma (ESCC) and head and neck squamous cell carcinoma (HNSCC) synchronously. Location of (a) oropharynx, (b) uvula, (c) upper thoracic esophagus, and (d) lower thoracic esophagus. Lesions are indicated by arrowheads; (B): (a) normal esophageal mucosa, (b) esophageal mucosa with multiple dysplastic lesions known as multiple Lugol-voiding lesions. Scale bar $=0.5 \mathrm{~cm}$.

\section{Blood and Salivary Acetaldehyde Level after Alcohol Intake}

Alcohol consumption increases acetaldehyde concentrations in the blood, saliva, and breath [29, 34,35]. In particular, acetaldehyde concentration reaches a very high level in saliva compared with blood [6]. When $A L D H 2^{*} 1 /{ }^{*} 1$ or $A L D H 2^{*} 1 /{ }^{*} 2$ carriers drink $0.6 \mathrm{~g}$ ethanol $/ \mathrm{kg}$ body weight, salivary acetaldehyde concentrations immediately reach 24 to $53 \mu \mathrm{M}$ in $A L D H 2^{*} 1 /{ }^{*} 1$ carriers and 37 to $76 \mu \mathrm{M}$ in $A L D H 2{ }^{*} 1 /{ }^{*} 2$ carriers, respectively [36]. The reason for the high acetaldehyde concentrations in saliva is considered to be associated with the formation of acetaldehyde from ethanol via microbial [6] and/or mucosal ADH [37]. Moreover, secretion from salivary glands also influences acetaldehyde concentration in saliva. Indeed, alcohol drinking ( $0.5 \mathrm{~g}$ ethanol $/ \mathrm{kg}$ body weight) increases acetaldehyde concentrations in parotid duct saliva on $A L D H 2 * 1 /{ }^{*} 2$ carriers, while it does not affect those on $A L D H 2{ }^{*} 1 /{ }^{*} 1$ carriers [38]. Furthermore, breath acetaldehyde is also thought to dissolve into saliva. The acetaldehyde concentrations in the oral cavity thus produced are equivalent to the concentration that can induce DNA damage in vitro $[6,38]$. Therefore, alcohol consumption in $A L D H 2^{*} 1 /^{*} 2$ carriers could promote the direct contact of high acetaldehyde-containing saliva to the surface of the oropharynx, hypopharynx, and esophagus and has the potential to induce DNA damage in the squamous epithelium. Taken together, sustained high acetaldehyde-containing saliva is considered to play an important role in the carcinogenesis of upper digestive tract cancers and it could be involved in "field cancerization."

\section{Acetaldehyde Reacts with DNA to Form DNA Adducts}

Acetaldehyde reacts directly with the exocyclic amino group of deoxyguanosine (dG) to form DNA adducts such as $N^{2}$-ethylidene- $2^{\prime}$-deoxyguanosine ( $N^{2}$-ethylidene-dG) [39], $N^{2}$-ethyl-2' ${ }^{\prime}$-deoxyguanosine $\left(N^{2}\right.$-Et-dG) [40,41], and $\alpha$-S- and $\alpha$-R-methyl- $\gamma$-hydroxy-1, $N^{2}$-propano- $2^{\prime}$-deoxyguanosine (CrPdG) (Figure 3) [39,42].

$N^{2}$-ethylidene-dG is generated by a single molecule of acetaldehyde and is the most abundant DNA adduct derived from acetaldehyde [43]. $N^{2}$-ethylidene-dG is unstable at the nucleoside level 
and is therefore difficult to measure [39]. $N^{2}$-ethylidene-dG can be stabilized by the chemical reduction of the Schiff base to the stable product, $N^{2}$-Et-dG. As endogenous $N^{2}$-Et-dG is extremely low, the level of $N^{2}$-Et-dG that is converted from $N^{2}$-ethylidene-dG by chemical reduction (e.g., $\mathrm{NaBH}_{3} \mathrm{CN}$ ) indicates the endogenous $N^{2}$-ethylidene-dG level [44]. Thus, $N^{2}$-ethylidene-dG is used for analysis of acetaldehyde-mediated DNA damage $[43,45,46]$ as a biomarker for acetaldehyde-specific DNA damage [47]. Indeed, alcohol consumption increases oral $N^{2}$-ethylidene-dG levels [48,49]. Furthermore, blood $N^{2}$-ethylidene-dG levels are definitely increased by alcohol consumption [50] and/or tobacco smoking [51]. Additionally, blood $N^{2}$-ethylidene-dG levels in alcoholics with the $A L D H 2 * 2$ allele are higher than those with the $A L D H 2 * 1 /{ }^{*} 1$ allele [46]. Importantly, alcohol consumption increases the esophageal $N^{2}$-ethylidene-dG levels in Aldh2-knockout mice to a higher level than that of wild-type mice $[47,52]$. This evidence indicates that drinking alcohol definitely increases acetaldehyde exposure to the esophageal tissues in individuals with the $A L D H 2 * 2$ allele.

CrPdG is generated by the reaction of two molecules of acetaldehyde with DNA [53] and exists in a ring-opened or ring-closed form [54,55]. Here, two molecules of acetaldehyde are converted into crotonaldehyde and then react with DNA to form CrPdG [56]. The levels of CrPdG are also related to the amount of acetaldehyde produced [57].

An ethenobase adduct, $1, N^{2}$-etheno- $2^{\prime}$-deoxyguanosine $(\mathrm{N} \varepsilon \mathrm{G})$, is generated in human cells treated with acetaldehyde [53]. $\mathrm{N} \varepsilon \mathrm{G}$ is a product from $2^{\prime}$-deoxyguanosine and $\alpha, \beta$-unsaturated aldehydes that can be formed during lipid peroxidation mediated by acetaldehyde (Figure 3) [53,58]. As acetaldehyde induces reactive oxygen species (ROS) that leads to lipid peroxidation [59], generation of $\mathrm{N \varepsilon G}$ can be triggered by acetaldehyde, ROS, or both.

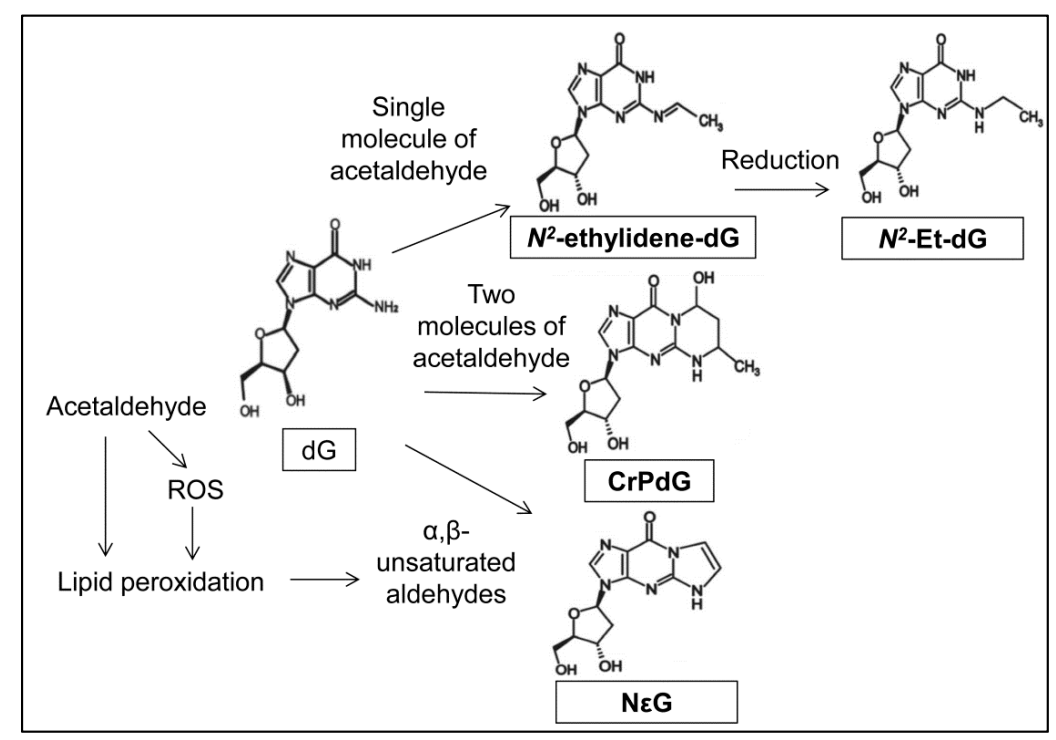

Figure 3. Formation of acetaldehyde-mediated DNA adducts. A single molecule of acetaldehyde reacts with deoxyguanosine $(\mathrm{dG})$ to generate $N^{2}$-ethylidene- $2^{\prime}$-deoxyguanosine ( $N^{2}$-ethylidene- $\left.\mathrm{dG}\right)$, which can be reduced to the stable adducts, $N^{2}$-ethyl-2'-deoxyguanosine ( $N^{2}$-Et-dG). $\alpha$-S- and $\alpha$ - $R$-methyl- $\gamma$-hydroxy- 1 , $N^{2}$-propano- $2^{\prime}$-deoxyguanosine $(\mathrm{CrPdG})$ is derived from $\mathrm{dG}$ and two molecules of acetaldehyde. $N^{2}$-etheno-2'-deoxyguanosine $(\mathrm{N} \varepsilon \mathrm{G})$ is formed from $\mathrm{dG}$ and $\alpha, \beta$-unsaturated aldehydes during lipid peroxidation, which is mediated by acetaldehyde or reactive oxygen species (ROS).

\section{DNA Adducts Induce Severe DNA Damage}

$N^{2}$-Et-dG blocks DNA synthesis and induces DNA mutations [60-63]. Moreover, $N^{2}$-Et-dG inhibits translesion DNA synthesis (TLS), which leads to a majority of frameshift deletions and a minority of G:C > T:A transversions in human cells [62]. $N^{2}$-Et-dG can rotate around the exocyclic nitrogen and the alpha carbon of acetaldehyde because it has a single bond, whereas $N^{2}$-ethylidene-dG has a double bond, 
which makes it more hydrophobic than $N^{2}$-Et-dG. These differences may result in significantly different mutagenic potential between $N^{2}$-Et-dG and $N^{2}$-ethylidene-dG [2].

CrPdG induces DNA interstrand [64] and intrastrand cross-links [65]. The ring-opened form of CrPdG can react with dG on the opposite strand of the DNA to form DNA interstrand cross-links [66]. A similar mechanism has been suggested for the formation of DNA intrastrand cross-links [2]. Whereas the ring-closed form of CrPdG would prevent Watson-Crick base pairing with cytosine in the anti conformation, Hoogsteen base pairing with cytosine would be possible in the syn conformation [55]. CrPdG-mediated disruption of the DNA replication process is thought to cause DNA damage [55,67-69].

$\mathrm{N} \varepsilon \mathrm{G}$ inhibits a replicative polymerase $\delta$ in complex with proliferating cell nuclear antigen (PCNA) while translesion polymerases $\eta, l$, and $k$ can bypass the lesion with varying mutagenic consequences [70-72]. In cells, replication of a plasmid containing a site-specific $N \varepsilon G$ induces base-pair mutations at the $\mathrm{N} \varepsilon \mathrm{G}$ site as well as deletions, rearrangements, double mutants, and base-pair substitutions near the $\mathrm{N} \varepsilon \mathrm{G}$ site [73]. These mutations near the $\mathrm{N} \varepsilon \mathrm{G}$ site could be triggered by error-prone processing of DNA double-strand breaks (DSBs) resulting from a replication fork collapse caused by $\mathrm{N} \varepsilon \mathrm{G}$ [2]. Certainly, acetaldehyde blocks DNA replication and increases the level of phosphorylated histone $\mathrm{H} 2 \mathrm{AX}(\gamma-\mathrm{H} 2 \mathrm{AX})$, a DSB marker, in cells [74].

Acetaldehyde exposure of human cells increases rates of sister chromatid exchange (SCE) [75]. $\mathrm{SCE}$ is thought to result from replication-blocking DNA lesions [76]. Although CrPdGs, NeG, and interstrand cross-links are shown to inhibit replication, the adducts or cross-links that relate to the formation of SCEs have not been elucidated.

\section{Carcinogenic Effects of Acetaldehyde}

To elaborate on details mentioned previously in part, acetaldehyde causes DNA adducts [39-42], DNA single-strand breaks, DSBs [77], point mutations [69], SCEs [78-80], DNA-DNA cross-links [81], micronuclei [82], and gross chromosomal aberrations [65,80]. Accumulations of these genetic abnormalities are considered to proceed cancer development. Exposure of acetaldehyde directly induces mutations, most frequently G:C > A:T transitions in the TP53 gene [83]. This transition pattern is consistent with that found in a study of the HPRT reporter gene [69]. In addition, G:C > T:A transversions are the most frequent miscoding events induced by CrPdG, followed by G:C > C:G and G:C > A:T mutations [67-69]. This spectrum of mutations corresponds with the gene variation pattern observed in ESCC $[84,85]$ and HNSCC [86]. Furthermore, inhalation of acetaldehyde causes nasal and respiratory squamous cell carcinoma in rats and hamsters $[87,88]$. These results indicate that acetaldehyde has direct carcinogenic effects in animals.

\section{Repair Pathways of Acetaldehyde-Mediated DNA Damage}

Recent research has revealed that cells coordinate multiple processes, such as the Fanconi anemia (FA) pathway, nucleotide excision repair (NER), homologous recombination (HR), TLS, base excision repair (BER), fork protection complex, and ATR-dependent cell cycle checkpoint activation, to prevent and repair acetaldehyde-mediated DNA damage [89].

The specific repair processes for $N^{2}$-ethylidene-dG and $N^{2}$-Et-dG remain unknown. The efforts to identify the repair mechanism for $N^{2}$-Et-dG are reported to be unsuccessful $[2,90]$.

The most plausible repair pathway of CrPdG is NER [91]. CrPdG generates interstrand cross-links [64], which can be repaired by the FA pathway [2]. This pathway is composed of at least 19 genes (FANCA, $B, C, D 1, D 2, E-G, I, J, L-T)$ and the deficiency of these genes can cause FA [92]. FANCA, B, C, E-G, L, and $\mathrm{M}$ form a core complex at the site of interstrand cross-links and then promote ubiquitination of the FANCD2-FANCI complex. This ubiquitination leads to the activation of downstream effector proteins, FANCD1, O, P, and Q. They promote the nucleolytic processing of interstrand cross-links, followed by DNA repair via HR [93-97]. Indeed, the FA-BRCA network is activated when cells are treated with ethanol or aldehyde $[98,99]$. Cells derived from an FA patient are hypersensitive to acetaldehyde exposure $[99,100]$. Cells deficient for FANCG, FANCQ, or HR protein Rad51D 
also show many chromosomal aberrations in response to acetaldehyde, while cells deficient for BER and nonhomologous end-joining show subtle increases in chromosome aberration [101,102].

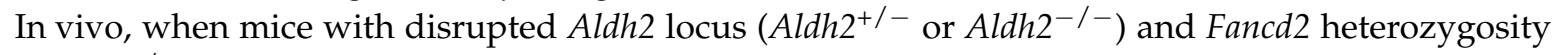
$\left(\right.$ Fancd $\left.^{+/-}\right)$are crossed and then challenged with ethanol exposure, the numbers of double-knockout offspring (Aldh2 $2^{-/-}$, Fancd $2^{-/}$) are significantly reduced [103]. Treatment with ethanol in adult double-knockout mice $\left(\right.$ Aldh2 $2^{-/}$, Fancd $2^{-/-}$) results in dramatic reductions of bone marrow cells. Moreover, these mice develop leukemia, even without ethanol administration [103]. These results indicate that Fancd 2 plays an important role in the protection from acetaldehyde-induced genotoxicity.

Acetaldehyde-mediated DSB is repaired by HR [74]. Acetaldehyde accumulates $\gamma-\mathrm{H} 2 \mathrm{AX}$, which colocalizes with foci of the HR protein Rad51 in cells [74]. Moreover, recombination-defective cells are hypersensitive to acetaldehyde [74].

\section{Prevention of Acetaldehyde-Mediated DNA Damage}

Acetaldehyde-mediated DNA damage is influenced by ALDH2 expression level [52]. ALDH2 is known to express in various tissues including the liver, kidney, muscle, and heart [104]. Recently, we found that alcohol consumption in mice promoted ALDH2 protein production in esophageal epithelium [52]. In vitro experiments revealed that ALDH2 is induced by acetaldehyde exposure in esophageal keratinocytes. ALDH2 knockdown resulted in an increase of susceptibility to acetaldehyde. Conversely, ALDH2 overexpression prevented acetaldehyde-mediated DNA damage in esophageal keratinocytes, although overexpression of mutant ALDH2 $(A L D H 2 * 2)$ offered no protection. Thus, enhancement of ALDH2 expression level may prevent acetaldehyde-mediated DNA damage.

\section{Conclusions}

Previous studies have provided substantial evidence that acetaldehyde induces various forms of DNA damage leading to cancer development (Figure 4). DNA adduct formation might be the key to acetaldehyde-mediated DNA damage; however, the role of DNA adducts in carcinogenesis has not been completely elucidated. Further studies are necessary to reveal the complete mechanisms of acetaldehyde-mediated cancer development.

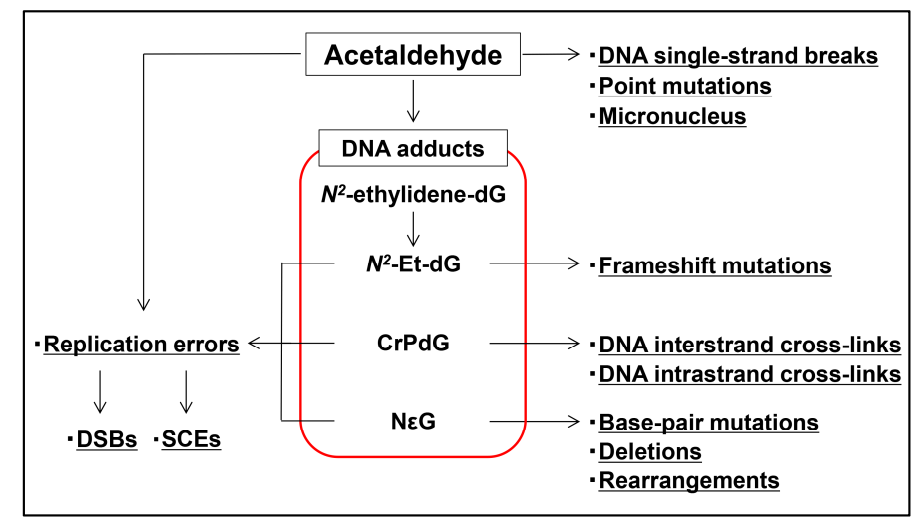

Figure 4. Summary of acetaldehyde-mediated DNA damage. Acetaldehyde causes DNA adducts, DNA single-strand breaks, DNA double-strand breaks (DSBs), point mutations, micronuclei, frameshift mutations, base-pair mutations, deletions, DNA-DNA interstrand or intrastrand cross-links, rearrangements, and sister chromatid exchanges (SCEs). DNA adducts are considered to be partly (but deeply) involved in their formation.

Acknowledgments: This work was supported by a Grant-in-Aid for Scientific Research 16K09281 (Shinya Ohashi), the Takeda Science Foundation (Shinya Ohashi), and for practical research for innovative cancer control from the Japan Agency for Medical Research and Development, AMED (Manabu Muto). None of the funding sources contributed to the writing of the manuscript. 
Conflicts of Interest: The authors declare that they have no competing interests.

\section{Abbreviations}

ADH1B
ALDH2
BER
CrPdG
dG
DSB
ESCC
FA
HNSCC
HR
LVL
NER
$N^{2}-E t-d G$
$N^{2}-e t h y l i d e n e-d G$
NeG
PCNA
ROS
SCE
TLS
$\gamma$-H2AX

\author{
Alcohol dehydrogenase 1B \\ Aldehyde dehydrogenase 2 \\ Base excision repair \\ $\alpha$-S- and $\alpha$-R-methyl- $\gamma$-hydroxy- $1, N^{2}$-propano-2'-deoxyguanosine \\ Deoxyguanosine \\ Double-strand break \\ Esophageal squamous cell carcinoma \\ Fanconi anemia \\ Head and neck squamous cell carcinoma \\ Homologous recombination \\ Lugol-voiding lesion \\ Nucleotide excision repair \\ $N^{2}$-ethyl-2'-deoxyguanosine \\ $N^{2}$-ethylidene-2'-deoxyguanosine \\ $1, N^{2}$-etheno-2'-deoxyguanosine \\ Proliferating cell nuclear antigen \\ Reactive oxygen species \\ Sister chromatid exchange \\ Translesion DNA synthesis \\ Phosphorylated histone H2AX
}

\section{References}

1. Seitz, H.K.; Stickel, F. Molecular mechanisms of alcohol-mediated carcinogenesis. Nat. Rev. Cancer 2007, 7, 599-612. [CrossRef] [PubMed]

2. Brooks, P.J.; Zakhari, S. Acetaldehyde and the genome: Beyond nuclear DNA adducts and carcinogenesis. Environ. Mol. Mutagen. 2014, 55, 77-91. [CrossRef] [PubMed]

3. Uebelacker, M.; Lachenmeier, D.W. Quantitative determination of acetaldehyde in foods using automated digestion with simulated gastric fluid followed by headspace gas chromatography. J. Autom. Methods Manag. Chem. 2011, 2011, 907317. [CrossRef] [PubMed]

4. Launoy, G.; Milan, C.; Day, N.E.; Pienkowski, M.P.; Gignoux, M.; Faivre, J. Diet and squamous-cell cancer of the oesophagus: A french multicentre case-control study. Int. J. Cancer 1998, 76, 7-12. [CrossRef]

5. Salaspuro, V.J.; Hietala, J.M.; Marvola, M.L.; Salaspuro, M.P. Eliminating carcinogenic acetaldehyde by cysteine from saliva during smoking. Cancer Epidemiol. Biomark. Prev. 2006, 15, 146-149. [CrossRef] [PubMed]

6. Homann, N.; Jousimies-Somer, H.; Jokelainen, K.; Heine, R.; Salaspuro, M. High acetaldehyde levels in saliva after ethanol consumption: Methodological aspects and pathogenetic implications. Carcinogenesis 1997, 18, 1739-1743. [CrossRef] [PubMed]

7. Salaspuro, M.P. Acetaldehyde, microbes, and cancer of the digestive tract. Crit. Rev. Clin. Lab. Sci. 2003, 40, 183-208. [CrossRef] [PubMed]

8. Muto, M.; Hitomi, Y.; Ohtsu, A.; Shimada, H.; Kashiwase, Y.; Sasaki, H.; Yoshida, S.; Esumi, H. Acetaldehyde production by non-pathogenic neisseria in human oral microflora: Implications for carcinogenesis in upper aerodigestive tract. Int. J. Cancer 2000, 88, 342-350. [CrossRef]

9. Linderborg, K.; Joly, J.P.; Visapaa, J.P.; Salaspuro, M. Potential mechanism for calvados-related oesophageal cancer. Food Chem. Toxicol. 2008, 46, 476-479. [CrossRef] [PubMed]

10. Linderborg, K.; Salaspuro, M.; Vakevainen, S. A single sip of a strong alcoholic beverage causes exposure to carcinogenic concentrations of acetaldehyde in the oral cavity. Food Chem. Toxicol. 2011, 49, 2103-2106. [CrossRef] [PubMed] 
11. Brooks, P.J.; Enoch, M.A.; Goldman, D.; Li, T.K.; Yokoyama, A. The alcohol flushing response: An unrecognized risk factor for esophageal cancer from alcohol consumption. PLoS Med. 2009, 6, e50. [CrossRef] [PubMed]

12. Ohashi, S.; Miyamoto, S.; Kikuchi, O.; Goto, T.; Amanuma, Y.; Muto, M. Recent advances from basic and clinical studies of esophageal squamous cell carcinoma. Gastroenterology 2015, 149, 1700-1715. [CrossRef] [PubMed]

13. Matsuo, K.; Hamajima, N.; Shinoda, M.; Hatooka, S.; Inoue, M.; Takezaki, T.; Tajima, K. Gene-environment interaction between an aldehyde dehydrogenase-2 (ALDH2) polymorphism and alcohol consumption for the risk of esophageal cancer. Carcinogenesis 2001, 22, 913-916. [CrossRef] [PubMed]

14. Yang, S.J. Relationship between genetic polymorphisms of ALDH2 and ADH1B and esophageal cancer risk: A meta-analysis. World J. Gastroenterol. 2010, 16, 4210. [CrossRef] [PubMed]

15. Yokoyama, A.; Muramatsu, T.; Omori, T.; Yokoyama, T.; Matsushita, S.; Higuchi, S.; Maruyama, K.; Ishii, H. Alcohol and aldehyde dehydrogenase gene polymorphisms and oropharyngolaryngeal, esophageal and stomach cancers in japanese alcoholics. Carcinogenesis 2001, 22, 433-439. [CrossRef] [PubMed]

16. Lachenmeier, D.W.; Salaspuro, M. ALDH2-deficiency as genetic epidemiologic and biochemical model for the carcinogenicity of acetaldehyde. Regul. Toxicol. Pharmacol. 2017, 86, 128-136. [CrossRef] [PubMed]

17. Neumark, Y.D.; Friedlander, Y.; Durst, R.; Leitersdorf, E.; Jaffe, D.; Ramchandani, V.A.; O'Connor, S.; Carr, L.G.; Li, T.K. Alcohol dehydrogenase polymorphisms influence alcohol-elimination rates in a male jewish population. Alcohol Clin. Exp. Res. 2004, 28, 10-14. [CrossRef] [PubMed]

18. Zhang, L.; Jiang, Y.; Wu, Q.; Li, Q.; Chen, D.; Xu, L.; Zhang, C.; Zhang, M.; Ye, L. Gene-Environment interactions on the risk of esophageal cancer among Asian populations with the G48A polymorphism in the alcohol dehydrogenase-2 gene: A meta-analysis. Tumour Biol. 2014, 35, 4705-4717. [CrossRef] [PubMed]

19. Zhang, Y.; Gu, N.; Miao, L.; Yuan, H.; Wang, R.; Jiang, H. Alcohol dehydrogenase-1B Arg47His polymorphism is associated with head and neck cancer risk in Asian: A meta-analysis. Tumour Biol. 2015, 36, 1023-1027. [CrossRef] [PubMed]

20. Enomoto, N.; Takase, S.; Yasuhara, M.; Takada, A. Acetaldehyde metabolism in different aldehyde dehydrogenase-2 genotypes. Alcohol Clin. Exp. Res. 1991, 15, 141-144. [CrossRef] [PubMed]

21. Hoshi, H.; Hao, W.; Fujita, Y.; Funayama, A.; Miyauchi, Y.; Hashimoto, K.; Miyamoto, K.; Iwasaki, R.; Sato, Y.; Kobayashi, T.; et al. Aldehyde-stress resulting from ALDH2 mutation promotes osteoporosis due to impaired osteoblastogenesis. J. Bone Miner. Res. 2012, 27, 2015-2023. [CrossRef] [PubMed]

22. Yokoyama, A.; Mizukami, T.; Yokoyama, T. Genetic polymorphisms of alcohol dehydrogense-1B and aldehyde dehydrogenase-2, alcohol flushing, mean corpuscular volume, and aerodigestive tract neoplasia in japanese drinkers. Adv. Exp. Med. Biol. 2015, 815, 265-279. [PubMed]

23. Harada, S.; Agarwal, D.P.; Goedde, H.W. Aldehyde dehydrogenase deficiency as cause of facial flushing reaction to alcohol in Japanese. Lancet (Lond. Engl.) 1981, 2, 982. [CrossRef]

24. Yoshida, A.; Huang, I.Y.; Ikawa, M. Molecular abnormality of an inactive aldehyde dehydrogenase variant commonly found in orientals. Proc. Natl. Acad. Sci. USA 1984, 81, 258-261. [CrossRef] [PubMed]

25. Higuchi, S.; Matsushita, S.; Murayama, M.; Takagi, S.; Hayashida, M. Alcohol and aldehyde dehydrogenase polymorphisms and the risk for alcoholism. Am. J. Psychiatry 1995, 152, 1219-1221. [PubMed]

26. Goedde, H.W.; Agarwal, D.P.; Fritze, G.; Meier-Tackmann, D.; Singh, S.; Beckmann, G.; Bhatia, K.; Chen, L.Z.; Fang, B.; Lisker, R.; et al. Distribution of ADH2 and ALDH2 genotypes in different populations. Hum. Genet. 1992, 88, 344-346. [CrossRef] [PubMed]

27. Boccia, S.; Hashibe, M.; Galli, P.; De Feo, E.; Asakage, T.; Hashimoto, T.; Hiraki, A.; Katoh, T.; Nomura, T.; Yokoyama, A.; et al. Aldehyde dehydrogenase 2 and head and neck cancer: A meta-analysis implementing a mendelian randomization approach. Cancer Epidemiol. Biomark. Prev. 2009, 18, 248-254. [CrossRef] [PubMed]

28. Secretan, B.; Straif, K.; Baan, R.; Grosse, Y.; El Ghissassi, F.; Bouvard, V.; Benbrahim-Tallaa, L.; Guha, N.; Freeman, C.; Galichet, L.; et al. A review of human carcinogens-Part E: Tobacco, areca nut, alcohol, coal smoke, and salted fish. Lancet Oncol. 2009, 10, 1033-1034. [CrossRef]

29. Muto, M.; Nakane, M.; Hitomi, Y.; Yoshida, S.; Sasaki, S.; Ohtsu, A.; Yoshida, S.; Ebihara, S.; Esumi, H. Association between aldehyde dehydrogenase gene polymorphisms and the phenomenon of field cancerization in patients with head and neck cancer. Carcinogenesis 2002, 23, 1759-1765. [CrossRef] [PubMed]

30. Mori, M.; Adachi, Y.; Matsushima, T.; Matsuda, H.; Kuwano, H.; Sugimachi, K. Lugol staining pattern and histology of esophageal lesions. Am. J. Gastroenterol. 1993, 88, 701-705. [PubMed] 
31. Muto, M.; Hironaka, S.; Nakane, M.; Boku, N.; Ohtsu, A.; Yoshida, S. Association of multiple lugol-voiding lesions with synchronous and metachronous esophageal squamous cell carcinoma in patients with head and neck cancer. Gastrointest. Endosc. 2002, 56, 517-521. [CrossRef]

32. Slaughter, D.P.; Southwick, H.W.; Smejkal, W. Field cancerization in oral stratified squamous epithelium; clinical implications of multicentric origin. Cancer 1953, 6, 963-968. [CrossRef]

33. Katada, C.; Yokoyama, T.; Yano, T.; Kaneko, K.; Oda, I.; Shimizu, Y.; Doyama, H.; Koike, T.; Takizawa, K.; Hirao, M.; et al. Alcohol consumption and multiple dysplastic lesions increase risk of squamous cell carcinoma in the esophagus, head, and neck. Gastroenterology 2016, 151, 860-869. [CrossRef] [PubMed]

34. Yokoyama, A.; Tsutsumi, E.; Imazeki, H.; Suwa, Y.; Nakamura, C.; Yokoyama, T. Polymorphisms of alcohol dehydrogenase-1B and aldehyde dehydrogenase-2 and the blood and salivary ethanol and acetaldehyde concentrations of japanese alcoholic men. Alcohol Clin. Exp. Res. 2010, 34, 1246-1256. [CrossRef] [PubMed]

35. Aoyama, I.; Ohashi, S.; Amanuma, Y.; Hirohashi, K.; Mizumoto, A.; Funakoshi, M.; Tsurumaki, M.; Nakai, Y.; Tanaka, K.; Hanada, M.; et al. Establishment of a quick and highly accurate breath test for ALDH2 genotyping. Clin. Transl. Gastroenterol. 2017, 8, e96. [CrossRef] [PubMed]

36. Yokoyama, A.; Tsutsumi, E.; Imazeki, H.; Suwa, Y.; Nakamura, C.; Mizukami, T.; Yokoyama, T. Salivary acetaldehyde concentration according to alcoholic beverage consumed and aldehyde dehydrogenase-2 genotype. Alcohol Clin. Exp. Res. 2008, 32, 1607-1614. [CrossRef] [PubMed]

37. Dong, Y.J.; Peng, T.K.; Yin, S.J. Expression and activities of class IV alcohol dehydrogenase and class III aldehyde dehydrogenase in human mouth. Alcohol 1996, 13, 257-262. [CrossRef]

38. Vakevainen, S.; Tillonen, J.; Agarwal, D.P.; Srivastava, N.; Salaspuro, M. High salivary acetaldehyde after a moderate dose of alcohol in ALDH2-deficient subjects: Strong evidence for the local carcinogenic action of acetaldehyde. Alcohol Clin. Exp. Res. 2000, 24, 873-877. [CrossRef] [PubMed]

39. Wang, M.; McIntee, E.J.; Cheng, G.; Shi, Y.; Villalta, P.W.; Hecht, S.S. Identification of DNA adducts of acetaldehyde. Chem. Res. Toxicol. 2000, 13, 1149-1157. [CrossRef] [PubMed]

40. Fang, J.L.; Vaca, C.E. Development of a ${ }^{32}$ P-postlabelling method for the analysis of adducts arising through the reaction of acetaldehyde with 2'-deoxyguanosine-3'-monophosphate and DNA. Carcinogenesis 1995, 16, 2177-2185. [CrossRef] [PubMed]

41. Fang, J.L.; Vaca, C.E. Detection of DNA adducts of acetaldehyde in peripheral white blood cells of alcohol abusers. Carcinogenesis 1997, 18, 627-632. [CrossRef] [PubMed]

42. Hecht, S.S.; McIntee, E.J.; Wang, M. New DNA adducts of crotonaldehyde and acetaldehyde. Toxicology 2001, 166, 31-36. [CrossRef]

43. Matsuda, T.; Matsumoto, A.; Uchida, M.; Kanaly, R.A.; Misaki, K.; Shibutani, S.; Kawamoto, T.; Kitagawa, K.; Nakayama, K.I.; Tomokuni, K.; et al. Increased formation of hepatic $N^{2}$-ethylidene-2'-deoxyguanosine DNA adducts in aldehyde dehydrogenase 2-knockout mice treated with ethanol. Carcinogenesis 2007, 28, 2363-2366. [CrossRef] [PubMed]

44. Wang, M.; Yu, N.; Chen, L.; Villalta, P.W.; Hochalter, J.B.; Hecht, S.S. Identification of an acetaldehyde adduct in human liver DNA and quantitation as $N^{2}$-ethyldeoxyguanosine. Chem. Res. Toxicol. 2006, 19, 319-324. [CrossRef] [PubMed]

45. Nagayoshi, H.; Matsumoto, A.; Nishi, R.; Kawamoto, T.; Ichiba, M.; Matsuda, T. Increased formation of gastric $N^{2}$-ethylidene-2'-deoxyguanosine DNA adducts in aldehyde dehydrogenase-2 knockout mice treated with ethanol. Mutat. Res. 2009, 673, 74-77. [CrossRef] [PubMed]

46. Yukawa, Y.; Muto, M.; Hori, K.; Nagayoshi, H.; Yokoyama, A.; Chiba, T.; Matsuda, T. Combination of $\mathrm{ADH}_{1} \mathrm{~B}^{*}$ / $\mathrm{ALDH} 2 * 2$ polymorphisms alters acetaldehyde-derived DNA damage in the blood of japanese alcoholics. Cancer Sci. 2012, 103, 1651-1655. [CrossRef] [PubMed]

47. Yukawa, Y.; Ohashi, S.; Amanuma, Y.; Nakai, Y.; Tsurumaki, M.; Kikuchi, O.; Miyamoto, S.; Oyama, T.; Kawamoto, T.; Chiba, T.; et al. Impairment of aldehyde dehydrogenase 2 increases accumulation of acetaldehyde-derived DNA damage in the esophagus after ethanol ingestion. Am. J. Cancer Res. 2014, 4, 279-284. [PubMed]

48. Balbo, S.; Meng, L.; Bliss, R.L.; Jensen, J.A.; Hatsukami, D.K.; Hecht, S.S. Kinetics of DNA adduct formation in the oral cavity after drinking alcohol. Cancer Epidemiol. Biomark. Prev. 2012, 21, 601-608. [CrossRef] [PubMed] 
49. Balbo, S.; Juanes, R.C.; Khariwala, S.; Baker, E.J.; Daunais, J.B.; Grant, K.A. Increased levels of the acetaldehyde-derived DNA adduct $N^{2}$-ethyldeoxyguanosine in oral mucosa DNA from rhesus monkeys exposed to alcohol. Mutagenesis 2016, 31, 553-558. [CrossRef] [PubMed]

50. Balbo, S.; Hashibe, M.; Gundy, S.; Brennan, P.; Canova, C.; Simonato, L.; Merletti, F.; Richiardi, L.; Agudo, A.; Castellsague, X.; et al. $N^{2}$-ethyldeoxyguanosine as a potential biomarker for assessing effects of alcohol consumption on DNA. Cancer Epidemiol. Biomark. Prev. 2008, 17, 3026-3032. [CrossRef] [PubMed]

51. Chen, L.; Wang, M.; Villalta, P.W.; Luo, X.; Feuer, R.; Jensen, J.; Hatsukami, D.K.; Hecht, S.S. Quantitation of an acetaldehyde adduct in human leukocyte DNA and the effect of smoking cessation. Chem. Res Toxicol. 2007, 20, 108-113. [CrossRef] [PubMed]

52. Amanuma, Y.; Ohashi, S.; Itatani, Y.; Tsurumaki, M.; Matsuda, S.; Kikuchi, O.; Nakai, Y.; Miyamoto, S.; Oyama, T.; Kawamoto, T.; et al. Protective role of ALDH2 against acetaldehyde-derived DNA damage in oesophageal squamous epithelium. Sci. Rep. 2015, 5, 14142. [CrossRef] [PubMed]

53. Garcia, C.C.; Angeli, J.P.; Freitas, F.P.; Gomes, O.F.; de Oliveira, T.F.; Loureiro, A.P.; di Mascio, P.; Medeiros, M.H. $\left[{ }^{13} \mathrm{C}_{2}\right]$-acetaldehyde promotes unequivocal formation of $1, N^{2}$-propano-2'-deoxyguanosine in human cells. J. Am. Chem. Soc. 2011, 133, 9140-9143. [CrossRef] [PubMed]

54. Mao, H.; Schnetz-Boutaud, N.C.; Weisenseel, J.P.; Marnett, L.J.; Stone, M.P. Duplex DNA catalyzes the chemical rearrangement of a malondialdehyde deoxyguanosine adduct. Proc. Natl. Acad. Sci. USA 1999, 96, 6615-6620. [CrossRef] [PubMed]

55. Minko, I.G.; Kozekov, I.D.; Harris, T.M.; Rizzo, C.J.; Lloyd, R.S.; Stone, M.P. Chemistry and biology of DNA containing $1, N^{2}$-deoxyguanosine adducts of the $\alpha, \beta$-unsaturated aldehydes acrolein, crotonaldehyde, and 4-hydroxynonenal. Chem. Res. Toxicol. 2009, 22, 759-778. [CrossRef] [PubMed]

56. Theruvathu, J.A.; Jaruga, P.; Nath, R.G.; Dizdaroglu, M.; Brooks, P.J. Polyamines stimulate the formation of mutagenic 1, $N^{2}$-propanodeoxyguanosine adducts from acetaldehyde. Nucleic Acids Res. 2005, 33, 3513-3520. [CrossRef] [PubMed]

57. Matsuda, T.; Yabushita, H.; Kanaly, R.A.; Shibutani, S.; Yokoyama, A. Increased DNA damage in ALDH2-deficient alcoholics. Chem. Res. Toxicol. 2006, 19, 1374-1378. [CrossRef] [PubMed]

58. Loureiro, A.P.; di Mascio, P.; Gomes, O.F.; Medeiros, M.H. Trans,trans-2,4-decadienal-induced 1, $N^{2}$-etheno-2'-deoxyguanosine adduct formation. Chem. Res. Toxicol. 2000, 13, 601-609. [CrossRef] [PubMed]

59. Tanaka, K.; Whelan, K.A.; Chandramouleeswaran, P.M.; Kagawa, S.; Rustgi, S.L.; Noguchi, C.; Guha, M.; Srinivasan, S.; Amanuma, Y.; Ohashi, S.; et al. ALDH2 modulates autophagy flux to regulate acetaldehyde-mediated toxicity thresholds. Am. J. Cancer Res. 2016, 6, 781-796. [PubMed]

60. Matsuda, T.; Terashima, I.; Matsumoto, Y.; Yabushita, H.; Matsui, S.; Shibutani, S. Effective utilization of $N^{2}$-ethyl-2'-deoxyguanosine triphosphate during DNA synthesis catalyzed by mammalian replicative DNA polymerases. Biochemistry 1999, 38, 929-935. [CrossRef] [PubMed]

61. Terashima, I.; Matsuda, T.; Fang, T.W.; Suzuki, N.; Kobayashi, J.; Kohda, K.; Shibutani, S. Miscoding potential of the $N^{2}$-ethyl-2'-deoxyguanosine DNA adduct by the exonuclease-free klenow fragment of escherichia coli DNA polymerase i. Biochemistry 2001, 40, 4106-4114. [CrossRef] [PubMed]

62. Upton, D.C.; Wang, X.; Blans, P.; Perrino, F.W.; Fishbein, J.C.; Akman, S.A. Replication of $N^{2}$-ethyldeoxyguanosine DNA adducts in the human embryonic kidney cell line 293. Chem. Res. Toxicol. 2006, 19, 960-967. [CrossRef] [PubMed]

63. Perrino, F.W.; Blans, P.; Harvey, S.; Gelhaus, S.L.; McGrath, C.; Akman, S.A.; Jenkins, G.S.; LaCourse, W.R.; Fishbein, J.C. The $\mathrm{N}^{2}$-ethylguanine and the $\mathrm{O}^{6}$-ethyl- and $\mathrm{O}^{6}$-methylguanine lesions in DNA: Contrasting responses from the "bypass" DNA polymerase eta and the replicative DNA polymerase $\alpha$. Chem. Res. Toxicol. 2003, 16, 1616-1623. [CrossRef] [PubMed]

64. Brooks, P.J.; Theruvathu, J.A. DNA adducts from acetaldehyde: Implications for alcohol-related carcinogenesis. Alcohol 2005, 35, 187-193. [CrossRef] [PubMed]

65. Matsuda, T.; Kawanishi, M.; Yagi, T.; Matsui, S.; Takebe, H. Specific tandem GG to TT base substitutions induced by acetaldehyde are due to intra-strand crosslinks between adjacent guanine bases. Nucleic Acids Res. 1998, 26, 1769-1774. [CrossRef] [PubMed]

66. Cho, Y.J.; Wang, H.; Kozekov, I.D.; Kurtz, A.J.; Jacob, J.; Voehler, M.; Smith, J.; Harris, T.M.; Lloyd, R.S.; Rizzo, C.J.; et al. Stereospecific formation of interstrand carbinolamine DNA cross-links by crotonaldehyde- and acetaldehyde-derived $\alpha-\mathrm{CH}_{3}-\gamma-\mathrm{OH}-1, N^{2}$-propano-2'-deoxyguanosine adducts in the 5'-CpG-3' sequence. Chem. Res. Toxicol. 2006, 19, 195-208. [CrossRef] [PubMed] 
67. Fernandes, P.H.; Kanuri, M.; Nechev, L.V.; Harris, T.M.; Lloyd, R.S. Mammalian cell mutagenesis of the DNA adducts of vinyl chloride and crotonaldehyde. Environ. Mol. Mutagen. 2005, 45, 455-459. [CrossRef] [PubMed]

68. Stein, S.; Lao, Y.; Yang, I.Y.; Hecht, S.S.; Moriya, M. Genotoxicity of acetaldehyde- and crotonaldehyde-induced 1, $N^{2}$-propanodeoxyguanosine DNA adducts in human cells. Mutat. Res. 2006, 608, 1-7. [CrossRef] [PubMed]

69. Noori, P.; Hou, S.M. Mutational spectrum induced by acetaldehyde in the HPRT gene of human tymphocytes resembles that in the $p 53$ gene of esophageal cancers. Carcinogenesis 2001, 22, 1825-1830. [CrossRef] [PubMed]

70. Choi, J.Y.; Guengerich, F.P. Adduct size limits efficient and error-free bypass across bulky $N^{2}$-guanine DNA lesions by human DNA polymerase eta. J. Mol. Biol. 2005, 352, 72-90. [CrossRef] [PubMed]

71. Choi, J.Y.; Guengerich, F.P. Kinetic evidence for inefficient and error-prone bypass across bulky $N^{2}$-guanine DNA adducts by human DNA polymerase iota. J. Biol. Chem. 2006, 281, 12315-12324. [CrossRef] [PubMed]

72. Choi, J.Y.; Angel, K.C.; Guengerich, F.P. Translesion synthesis across bulky $N^{2}$-alkyl guanine DNA adducts by human DNA polymerase к. J. Biol Chem. 2006, 281, 21062-21072. [CrossRef] [PubMed]

73. Akasaka, S.; Guengerich, F.P. Mutagenicity of site-specifically located $1, N^{2}$-ethenoguanine in chinese hamster ovary cell chromosomal DNA. Chem. Res. Toxicol. 1999, 12, 501-507. [CrossRef] [PubMed]

74. Kotova, N.; Vare, D.; Schultz, N.; Gradecka Meesters, D.; Stepnik, M.; Grawe, J.; Helleday, T.; Jenssen, D. Genotoxicity of alcohol is linked to DNA replication-associated damage and homologous recombination repair. Carcinogenesis 2013, 34, 325-330. [CrossRef] [PubMed]

75. Jansson, T. The frequency of sister chromatid exchanges in human lymphocytes treated with ethanol and acetaldehyde. Hereditas 1982, 97, 301-303. [CrossRef] [PubMed]

76. Wilson, D.M., 3rd; Thompson, L.H. Molecular mechanisms of sister-chromatid exchange. Mutat. Res. 2007, 616, 11-23. [CrossRef] [PubMed]

77. Singh, N.P.; Khan, A. Acetaldehyde: Genotoxicity and cytotoxicity in human lymphocytes. Mutat. Res. 1995, 337, 9-17. [CrossRef]

78. Obe, G.; Jonas, R.; Schmidt, S. Metabolism of ethanol in vitro produces a compound which induces sister-chromatid exchanges in human peripheral lymphocytes in vitro: Acetaldehyde not ethanol is mutagenic. Mutat. Res. 1986, 174, 47-51. [CrossRef]

79. Dellarco, V.L. A mutagenicity assessment of acetaldehyde. Mutat. Res. 1988, 195, 1-20. [CrossRef]

80. Helander, A.; Lindahl-Kiessling, K. Increased frequency of acetaldehyde-induced sister-chromatid exchanges in human lymphocytes treated with an aldehyde dehydrogenase inhibitor. Mutat. Res. 1991, 264, $103-107$. [CrossRef]

81. Lambert, B.; Chen, Y.; He, S.M.; Sten, M. DNA cross-links in human leucocytes treated with vinyl acetate and acetaldehyde in vitro. Mutat. Res. 1985, 146, 301-303. [CrossRef]

82. Kayani, M.A.; Parry, J.M. The in vitro genotoxicity of ethanol and acetaldehyde. Toxicol. In Vitro 2010, 24, 56-60. [CrossRef] [PubMed]

83. Paget, V.; Lechevrel, M.; Sichel, F. Acetaldehyde-induced mutational pattern in the tumour suppressor gene tp53 analysed by use of a functional assay, the fasay (functional analysis of separated alleles in yeast). Mutat. Res. 2008, 652, 12-19. [CrossRef] [PubMed]

84. Lin, D.C.; Hao, J.J.; Nagata, Y.; Xu, L.; Shang, L.; Meng, X.; Sato, Y.; Okuno, Y.; Varela, A.M.; Ding, L.W.; et al. Genomic and molecular characterization of esophageal squamous cell carcinoma. Nat. Genet. 2014, 46, 467-473. [CrossRef] [PubMed]

85. Sawada, G.; Niida, A.; Uchi, R.; Hirata, H.; Shimamura, T.; Suzuki, Y.; Shiraishi, Y.; Chiba, K.; Imoto, S.; Takahashi, Y.; et al. Genomic landscape of esophageal squamous cell carcinoma in a Japanese population. Gastroenterology 2016, 150, 1171-1182. [CrossRef] [PubMed]

86. Cancer Genome Atlas, N. Comprehensive genomic characterization of head and neck squamous cell carcinomas. Nature 2015, 517, 576-582.

87. Woutersen, R.A.; Appelman, L.M.; van Garderen-Hoetmer, A.; Feron, V.J. Inhalation toxicity of acetaldehyde in rats. III. Carcinogenicity study. Toxicology 1986, 41, 213-231. [CrossRef]

88. Feron, V.J.; Kruysse, A.; Woutersen, R.A. Respiratory tract tumours in hamsters exposed to acetaldehyde vapour alone or simultaneously to benzo(a)pyrene or diethylnitrosamine. Eur. J. Cancer Clin. Oncol. 1982, 18, 13-31. [CrossRef] 
89. Noguchi, C.; Grothusen, G.; Anandarajan, V.; Martinez-Lage Garcia, M.; Terlecky, D.; Corzo, K.; Tanaka, K.; Nakagawa, H.; Noguchi, E. Genetic controls of DNA damage avoidance in response to acetaldehyde in fission yeast. Cell Cycle 2017, 16, 45-58. [CrossRef] [PubMed]

90. Koivisto, P.; Robins, P.; Lindahl, T.; Sedgwick, B. Demethylation of 3-methylthymine in DNA by bacterial and human DNA dioxygenases. J. Biol. Chem. 2004, 279, 40470-40474. [CrossRef] [PubMed]

91. Choudhury, S.; Pan, J.; Amin, S.; Chung, F.L.; Roy, R. Repair kinetics of trans-4-hydroxynonenal-induced cyclic 1,N2-propanodeoxyguanine DNA adducts by human cell nuclear extracts. Biochemistry 2004, 43, 7514-7521. [CrossRef] [PubMed]

92. Dong, H.; Nebert, D.W.; Bruford, E.A.; Thompson, D.C.; Joenje, H.; Vasiliou, V. Update of the human and mouse fanconi anemia genes. Hum. Genomics 2015, 9, 32. [CrossRef] [PubMed]

93. Clauson, C.; Scharer, O.D.; Niedernhofer, L. Advances in understanding the complex mechanisms of DNA interstrand cross-link repair. Cold Spring Harb. Perspect. Biol. 2013, 5, a012732. [CrossRef] [PubMed]

94. Kottemann, M.C.; Smogorzewska, A. Fanconi anaemia and the repair of watson and crick DNA crosslinks. Nature 2013, 493, 356-363. [CrossRef] [PubMed]

95. Moldovan, G.L.; D'Andrea, A.D. How the fanconi anemia pathway guards the genome. Annu. Rev. Genet. 2009, 43, 223-249. [CrossRef] [PubMed]

96. Walden, H.; Deans, A.J. The fanconi anemia DNA repair pathway: Structural and functional insights into a complex disorder. Annu. Rev. Biophys. 2014, 43, 257-278. [CrossRef] [PubMed]

97. Thompson, L.H.; Hinz, J.M. Cellular and molecular consequences of defective fanconi anemia proteins in replication-coupled DNA repair: Mechanistic insights. Mutat. Res. 2009, 668, 54-72. [CrossRef] [PubMed]

98. Abraham, J.; Balbo, S.; Crabb, D.; Brooks, P.J. Alcohol metabolism in human cells causes DNA damage and activates the fanconi anemia-breast cancer susceptibility (FA-BRCA) DNA damage response network. Alcohol Clin. Exp. Res. 2011, 35, 2113-2120. [CrossRef] [PubMed]

99. Marietta, C.; Thompson, L.H.; Lamerdin, J.E.; Brooks, P.J. Acetaldehyde stimulates FANCD2 monoubiquitination, H2AX phosphorylation, and BRCA1 phosphorylation in human cells in vitro: Implications for alcohol-related carcinogenesis. Mutat. Res. 2009, 664, 77-83. [CrossRef] [PubMed]

100. Obe, G.; Natarajan, A.T.; Meyers, M.; Hertog, A.D. Induction of chromosomal aberrations in peripheral lymphocytes of human blood in vitro, and of sces in bone-marrow cells of mice in vivo by ethanol and its metabolite acetaldehyde. Mutat. Res. 1979, 68, 291-294. [CrossRef]

101. Mechilli, M.; Schinoppi, A.; Kobos, K.; Natarajan, A.T.; Palitti, F. DNA repair deficiency and acetaldehyde-induced chromosomal alterations in CHO cells. Mutagenesis 2008, 23, 51-56. [CrossRef] [PubMed]

102. Lorenti Garcia, C.; Mechilli, M.; Proietti De Santis, L.; Schinoppi, A.; Kobos, K.; Palitti, F. Relationship between DNA lesions, DNA repair and chromosomal damage induced by acetaldehyde. Mutat. Res. 2009, 662, 3-9. [CrossRef] [PubMed]

103. Langevin, F.; Crossan, G.P.; Rosado, I.V.; Arends, M.J.; Patel, K.J. FANCD2 counteracts the toxic effects of naturally produced aldehydes in mice. Nature 2011, 475, 53-58. [CrossRef] [PubMed]

104. Stewart, M.J.; Malek, K.; Crabb, D.W. Distribution of messenger RNAs for aldehyde dehydrogenase 1, aldehyde dehydrogenase 2, and aldehyde dehydrogenase 5 in human tissues. J. Investig. Med. 1996, 44, 42-46. [PubMed]

(c) 2017 by the authors. Licensee MDPI, Basel, Switzerland. This article is an open access article distributed under the terms and conditions of the Creative Commons Attribution (CC BY) license (http://creativecommons.org/licenses/by/4.0/). 